Proc. Indian Acad. Sci. (Anim. Sci.), Vol. 89, Number 2, April 1980, pp. 165-170.

(C) Printed in India.

\title{
Environmental restraints on the food conversion of cyprinid forage fishes : Influence of availability of food on Rasbora daniconius (Hamilton)
}

\author{
R NAGENDRAN, R PONNUCHAMY and KATRE SHAKUNTALA \\ Department of Zoology, Bangalore University, Bangalore 560001 , India \\ MS received 6 October 1979; revised 16 January 1980
}

\begin{abstract}
The effects of food availability on the bioenergetics and the body composition of the cyprinid Rasbora daniconius (Ham.) have been described. During the 15-day experimental period, fish in the weight range of 475 to $1660 \mathrm{mg}$ were fed daily on Tubifex tubifex for different durations. The food intake increased from $7.96 \pm 2.323 \mathrm{mg} \mathrm{dry} /$ fish/day for fish exposed to food for $2 \mathrm{hr}$ to $11.57 \pm 0.757 \mathrm{mg}$ dry/fish/day for fish fed ad libitum diet. For the same series of fish, the feeding rate also increased. Growth of fish expressed as $\mathrm{mg}$ gain in dry weight/fish/day increased with increases in food intake. However, the food conversion efficiency was highly variable in relation to the daily food intake or feeding rate.
\end{abstract}

Keywords. Food availability; Rasbora daniconius; starvation; conversion; body composition.

\section{Introduction}

The importance of availability of food as a growth regulating factor in fishes has been stressed by Pandian and Raghuraman (1972) and Katre and Reddy (1978). While there are reports on the influence of availability of food on the growth of catfishes (Andrews and Page 1975), salmonids (Le Brasseur 1969; Elliot 1975a, b), cichlids (Hari Sethi 1970; Pandian and Raghuraman 1972) and cyprinodontids (Katre and Reddy 1978; Krishnamurthy 1978), similar studies are wanting in cyprinids. The present paper details the influence of the availability of food on the food conversion and body composition of the common cyprinid forage fish Rasbora daniconius.

\section{Material and methods}

Rasbora daniconitus were collected from a local freshwater tank, operating a drag net. The fish were acclimated in the laboratory for a week. Healthy individuals in the weight range of 475 to $1660 \mathrm{mg}$ were selected for the study. Experimental fish were grouped into seven series each with six fish reared individually in glass 
aquaria containing $500 \mathrm{ml}$ of freshwater. Fish were fed daily on surplus amounts, of the oligochaete worm Tubifex tubifex. Each series of fish was exposed to different durations of prey presence per day $(0,2,4,6,8$ and $12 \mathrm{hr} /$ day or ad libitum). After a 15-day experimental period, the average daily food intake, growth and conversion efficiency $\left(K_{1}=\%\right)$ of the fish were determined following the method of Katre and Reddy (1978). Chemical analyses of the fish were made on material dried to constant weight. Ash was determined following the method of Paine (1964). Organic matter was determined as the difference between the dry weight and the ash weight.

\section{Results and discussion}

Table 1 presents the influence of availability of food on the daily consumption growth and gross conversion efficiency of Rasbora daniconius. The food intake (mg dry/fish/day) increased from 7.96 土 2.323 for fish exposed to food for $2 \mathrm{hr} /$ day to $11.57 \pm 0.757$ for fish fed ad libitum diet. Marked differences in food intake were not observed between groups fed $2 \mathrm{hr} /$ day and $4 \mathrm{hr} /$ day or between $6 \mathrm{hr} /$ day and $8 \mathrm{hr} /$ day or between $12 \mathrm{hr} /$ day and $24 \mathrm{hr} /$ day. The cumulative average values of food intake for the above three series were $7 \cdot 69,9 \cdot 13$ and $11 \cdot 52 \mathrm{mg}$ dry/fish/day respectively. From this it appears that the food intake of fish per hour depended upon the prior starvation period. While fish fed after $21 \mathrm{hr}$ of starvation (average starvation period of fish fed 2 or $4 \mathrm{hr} /$ day) consumed $2.56 \mathrm{mg}$ dry food/fish/hr, $(7 \cdot 96+7 \cdot 42) /(2+4)$ those fed after $17 \mathrm{hr}(9 \cdot 00+9 \cdot 26) /(6+9)$ and $6 \mathrm{hr}(11 \cdot 46+11 \cdot 57) /(12+24)$ of starvation consumed $1 \cdot 31$ and $0.64 \mathrm{mg}$ dry food/fish/hr respectively. This suggests that in $R$. daniconius food consumption and amount of food per meal are influenced by the prior starvation period. Simi-

Table 1. Rasbora daniconius: Influence of food availability on the daily food intake, growth and conversion efficiency. Each value represents the mean of six individuals $( \pm=\mathrm{SD})$.

\begin{tabular}{|c|c|c|c|c|}
\hline $\begin{array}{l}\text { Food availa- } \\
\text { bility (hr/day) }\end{array}$ & $\begin{array}{c}\text { Food intake* } \\
(\mathrm{mg} \mathrm{dry} / \mathrm{fish} / \mathrm{day})\end{array}$ & $\begin{array}{c}\text { Feeding rate } \\
\text { (mg dry/g } \\
\text { fish/day) }\end{array}$ & $\begin{array}{c}\text { Growth } \\
\text { (mg dry/fish/day) }\end{array}$ & $\begin{array}{c}\text { Conversion efficiency } \\
\qquad\left(K_{1}=\%\right)\end{array}$ \\
\hline 0 & . & .. & $-2.972 \pm 0.237$ & .. \\
\hline 2 & a $7 \cdot 96 \pm 2 \cdot 323$ & $12 \cdot 00$ & $+0.921 \pm 0.046$ & $11 \cdot 80 \pm 6 \cdot 205$ \\
\hline 4 & b $7 \cdot 42 \pm 1 \cdot 026\}$ & $13 \cdot 09$ & $0.942 \pm 0.056$ & $13 \cdot 21 \pm 6 \cdot 205$ \\
\hline 6 & c $9 \cdot 00 \pm 1 \cdot 003\}$ & $15 \cdot 20$ & $1 \cdot 620 \pm 0 \cdot 398$ & $18 \cdot 13 \pm 4 \cdot 579$ \\
\hline 8 & $d 9 \cdot 26 \pm 1 \cdot 318\}$ & $15 \cdot 33$ & $1.759 \pm 0.812$ & $19 \cdot 44 \pm 10 \cdot 535$ \\
\hline 12 & e $11 \cdot 46 \pm 1 \cdot 581$ & $19 \cdot 22$ & $2 \cdot 776 \pm 1 \cdot 343$ & $23 \cdot 44 \pm 9 \cdot 609$ \\
\hline 24 & $f 11 \cdot 57 \pm 0.757\}$ & $21 \cdot 72$ & $2 \cdot 108 \pm 0 \cdot 384$ & $18 \cdot 23 \pm 3 \cdot 348$ \\
\hline (ad libitum) & & & & \\
\hline
\end{tabular}

${ }^{*} P$ values: Highly insignificant, $a=b: 1 \cdot 0632 . \quad c=d: 07 \cdot 850 . \quad e=f: 0 \cdot 3139$. 
lar increases in food intake/hr with increases in starvation period have been reported for the mosquito fish Gambusia affinis (Katre and Reddy 1978).

Fish are considered 'satiated' when they would no longer accept any food, after a period of active feeding, even in the presence of excess food (Brett 1971). Time taken by fish to attain satiation, i.e., the period of time elapsing from the start of aztive feeding to voluntary cessation is denoted as the 'satiation time' in fishes (Brett 1971; Niimi and Beamish 1974). In the present study the satiation time for $R$. dainiconius has not been resorded. However, the small difference in the food intake between groups fed for $2 \mathrm{hr} /$ day and $4 \mathrm{hr} /$ day indicates that an amount of dry worm s!bstance equivalent to $7 \cdot 96 \pm 2 \cdot 323 \mathrm{mg}$ represents the full capacity/ meal of the fish. Considering the daily food intake of $7.96 \mathrm{mg}$ for fish receiving a food st!pply for only $2 \mathrm{hr} / \mathrm{day}$ as a unit, if the increase in food intake to food exposure time was proportional, the fish should have consumed 12 times that amount $(95 \cdot 52 \mathrm{mg})$, when the feeding schedule was ad libitum $(24 \mathrm{hr} /$ day $)$. Figure 1 represents the expected and obtained values of food intake of $R$. daniconius with reference to the prey exposure time. From this it is evident that the experimental values deviate considerably from the expected values. For example, a value of $11.57 \pm 0.757 \mathrm{mg}$ for the ad libitum feeding is considerably low to the calculated value of $95.52 \mathrm{mg}$. This indicates that $R$. daniconius feeds intermittently and the amount of food per meal is neither always constant nor proportional to the period of exposure to food. A similar relationship between the availability of food per day and the daily food intake has been reported for Juvenile chum salmon, Oncorlyncinus keta (Le Brasseiı 1969), Gambusia affinis (Katre and Reddy 1978) and Poecilia reticulata (Krishnamurthy 1978). The larger deviations between the estimated and experimental values of food intake obtained presently (figure 1), as compared to those reported for $G$. affinis or $P$. reticulata may be due to the different feeding habits of the fishes. While $G$. affinis and $P$. reticulata are known to be basically larvivorous, feeding on live prey (Gerberich and Laird 1965), $R$. daniconius is more or less a herbivore with some omnivorous feeding habit (personal observation).

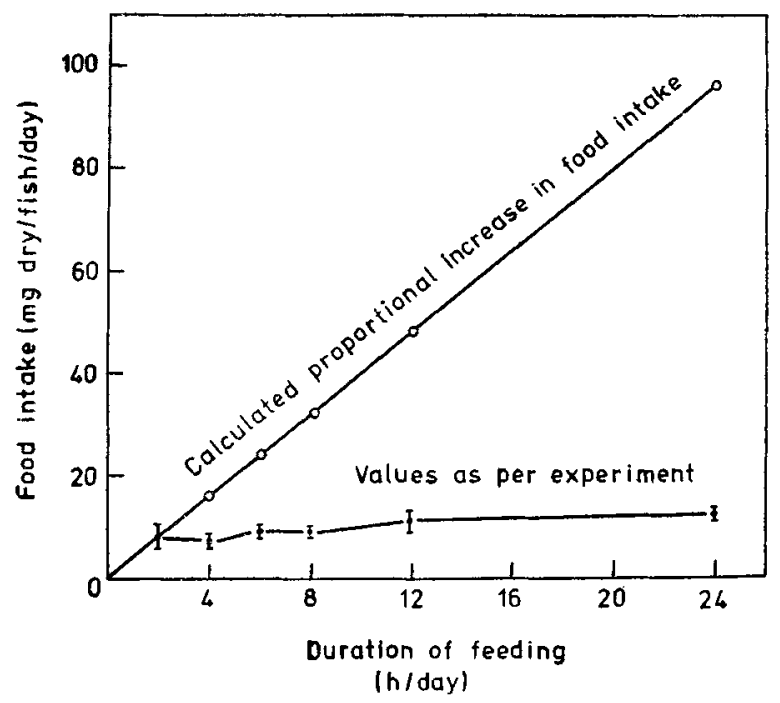

Figure 1. Calculated and experimental food intake of Rasbora daniconius. 
The calculated feeding rate expressed as $\mathrm{mg}$ dry food/g fish/day of Rasbora daniconius increased with increases in duration of feeding and fish fed on an ad libitum diet exhibited a maximum value of $21 \cdot 72$ (table 1 ). The present average value of feeding rate was $16.09 \mathrm{mg}$ dry $/ \mathrm{g}$ fish/day for a fish weighing on an average $674 \mathrm{mg}$. The present value is significantly higher as compared to a value of $9.306 \mathrm{mg}$ dry food/g fish/day reported for the same species fed on chopped pieces of earthworm (data recalculated from Raghuraman 1973). This indicates that $R$. daniconius feeds on Tubifex worms better than on earthworms. This may be due to the smaller size of the prey offered as well as its quality (Galinat 1960) and easy digestibility by the fish (Mann 1960).

Figure 2 indicates the relationship between the duration of feeding and growth. $R$. daniconius exhibited a loss of $2.97 \pm 0.237 \mathrm{mg}$ dry/fish/day on starvation during the experimental period. Growth ( $\mathrm{mg}$ dry/fish/day) of fish increased with increases in the duration of feeding upto the feeding schedule of $12 \mathrm{hr} /$ day, beyond which a decrease in the growth was observed (table 1). The values of daily growth also indicated considerable deviations from the calculated linear increases with increase in food supply (see also Le Brasseur 1969; Katre and Reddy 1978; Krishnamurthy 1978).

The mean values of conversion efficiency $\left(K_{1}=\%\right)$ of $R$. daniconius increased with increases in food supply ( $2 \mathrm{hr} /$ day: $11 \cdot 80$ 土. $6 \cdot 205 \%$; ad libitum: $18 \cdot 23$ 土 $3 \cdot 348 \%$ ). The maximum value of $23 \cdot 44 \pm 9 \cdot 609 \%$ was obtained for fish receiving food supply for $12 \mathrm{hr} /$ day. The average value of conversion efficiency obtained in the present study was $17 \cdot 38 \%$. A slightly lower value of $16 \cdot 36 \%$ has been indicated for the same species fed on earthworm (data recalculated from Raghuraman 1973). The better efficiency obtained presently may be attributed to the higher feeding rate as well as better utilisation of the Tubifex tubifex worms. After exami-

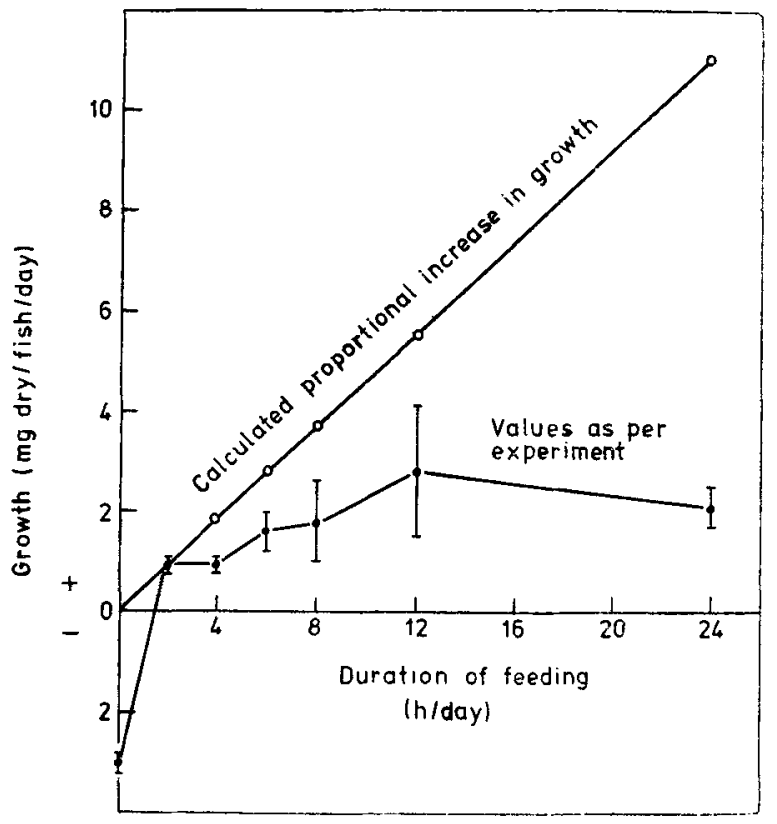

Figure 2. Calculated and experimental values of growth in Rasbora daniconius. 
ning the literature on food intake and growth of fishes, Paloheimo and Dickie (1965) concluded that gross conversion efficiency decreases from a maximum value at low feeding levels. However, the large deviations from the mean valles of conversion efficiency obtained presently do not permit further discussion on this aspect.

Table 2 presents the body composition of control and experimental fish. As compared to the controls, fish that were starved during the period of experiment exhibited a considerable increase in the ash content. Similar effect of starvation on the ash content have been reported for Tilapia mossambica (Pandian and Raghuraman 1972) and Lepomis macrochirus (Savitz 1971). However, no significant variations in ash content were observed between the controls and those receiving food for different durations per day. Experimental fish on starvation exhibited a considerable decrease in their organic matter indicating the definite utilisation of organic reserves for maintenance. Fish fed for different durations during the study did not exhibit any significant change in their organic components. This indicates that $R$. daniconius is able to obtain the necessary organic components for their maintenance even on a minimum feeding schedule of $2 \mathrm{hr} / \mathrm{day}$. The water content of fish fed on different feeding schedules did not indicate any marked variations from the values obtained for controls. In contrast to this, increases in water content on starvation have been reported for Salvelinus fontinalis (Phillips etal 1960) and Tilapia mossambica (Pandian and Raghuraman 1972). The increase in water content is usually attributed to the increased fat metabolism during starvation (see also Beamish et al 1975). The present observations indicate that in $R$. daniconius, at least during a short experimental period of 15 days, reserve fat may not be utilised for purposes of maintenance during starvation. However, extensive experimentation is needed to determine the actual source of nutrient depletion during starvation of $R$. daniconius.

Table 2. Rasbora daniconius: Body composition of control and experimental fish. Each value represents the mean of six estimates.

\begin{tabular}{|c|c|c|c|c|c|c|c|c|}
\hline \multirow{2}{*}{$\begin{array}{l}\text { Biochemical consti- } \\
\text { tuents determined }\end{array}$} & \multirow{2}{*}{$\begin{array}{l}\text { Initial fish } \\
\text { (control) }\end{array}$} & \multicolumn{7}{|c|}{ Experimental fish: Duration of feeding (h:r/day) } \\
\hline & & 0 & 2 & 4 & 6 & 8 & 12 & 24 \\
\hline Dry matter $(\%)$ & $24 \cdot 68$ & $24 \cdot 64$ & $25 \cdot 45$ & $24 \cdot 57$ & $25 \cdot 61$ & $24 \cdot 49$ & $27 \cdot 17$ & $26 \cdot 07$ \\
\hline Water $(\%)$ & $75 \cdot 32$ & $75 \cdot 36$ & $74 \cdot 55$ & $75 \cdot 43$ & $74 \cdot 39$ & $75 \cdot 51$ & $72 \cdot 83$ & $73 \cdot 93$ \\
\hline Ash ( $\%$ of dry matter) & $14 \cdot 52$ & $20 \cdot 12$ & $15 \cdot 88$ & $17 \cdot 65$ & $15 \cdot 01$ & $16 \cdot 92$ & $13 \cdot 58$ & $14 \cdot 69$ \\
\hline $\begin{array}{l}\text { Organic matter* } \\
\quad(\% \text { of dry matter })\end{array}$ & $85 \cdot 48$ & $79 \cdot 88$ & $84 \cdot 12$ & $82 \cdot 35$ & $84 \cdot 99$ & $83 \cdot 08$ & $86 \cdot 42$ & $85 \cdot 31$ \\
\hline
\end{tabular}

* Calculated data 


\section{Acknowledgement}

One of the authors (RN) acknowledges the fellowship from the Council of Scientific and Industrial Research, New Delhi.

\section{References}

Andrews J W and Page J W 1975 The effects of frequency of feeding on culture of catfish; Trans Am. Fish. Soc. 104 317-321

Beamish F W H, Niimi A J and Lett P F K P 1975 Bioenergetics of teleost fishes : Environmental influences: in Comparative physiology-functional aspects of structural materials eds L Bolis, H P Maddrell and K Schmidt-Nielsen (Amsterdam : North Holland) pp. 187-209

Brett J R 1971 Satiation time, appetite and maximum food intake of sockeye salmon (Oncorhynchus nerka); J. Fish. Res. Bd. Canada. 28 409-415

Elliot J M 1975a The growth rate of brown trout, Salmo trutta L., fed on maximum rations; J. Anim. Ecol. 44 805-821

Elliot J M 1975b The growth rate of brown trout (Salmo trutta L.) fed on reduced rations; J. Anim. Ecol. 44 823-842

Galinat A 1960 Experimental studies on the utilisation of natural food by young Crucian (Carassius carassius L.) and tench (Tinca tinca L.); Polskie Archiv. Hydrobiol. 8 129-152

Gerberich J B and Laird M 1965 An annotated bibliography of papers related to the control of mosquitoes by the use of fish; WHO/Mal/66-562

Hari Sethi S 1970 Temperature and bioenergetics of Cichlasoma bimaculatum, Ph.D. thesis, Oregon University

Katre S and Reddy S R 1978 Environmental restraints on the food intake, growth and conversion efficiency of Gambusia affinis : influence of availability of food; Comp. Physiol. Ecol. 3 258261

Krishnamurthy C 1978 Studies on food intake, growth and conversion efficiency of a larvivorous fish, M. Phil. thesis, Bangalore University

Le Brassuer R J 1969 Growth of juvenile chum salmon (Oncorhynchus keta) under different feeding regimes; J. Fish. Res. Bd. Canada. 26 1631-1645

Mann H 1935 Untersuchungen uber die Verdalliung and Ausntzung der Sticksoff suhstanz einiger Nahrtiere durch verschidene Fische; $Z$. Fisch. 33 231-274

Niimi A J and Beamish F W H 1974 Bioenergetics and growth of large mouth bass (Micropterus salmoides); Can. J. Zool. 52 447-456

Paine R T 1964 Ash and caloric determination of sponges and opisthobranch tissues; Ecology $45 \quad 384-387$

Paloheimo J E and Dickie L M 1965 Food and growth of fishes. I A growth curve derived from experimental data; J. Fish. Res. Bd. Canada 22 521-542

Pandian T J and Raghuraman R 1972 Effects of feeding rate on conversion efficiency and chemical composition of the fish, Tilapia mossambica; Mar. Biol. 12 129-136

Phillips A M, Livingston D L and Dumas R F 1960 Effect of starvation and feeding on the chemical composition of brook trout; Prog. Fish. Cult. 22 147-154

Raghuraman R 1973 Effect of body weight on intake and conversion of food in the fish Rasbora daniconius; Curr. Sci. 42 24-25

Savitz J 1971 Effects of starvation of body protein utilisation of Bluegill Sunfish (Lepomis macrochirus Rafinesque) with a calculation of caloric requirements; Trans. Am. Fish. Soc. 100 $18-21$ 